\title{
Inadequate budgets and salaries as instruments for institutionalizing public sector corruption in Indonesia
}

\author{
Ross H. McLeod
}

\begin{abstract}
Soeharto used the Indonesian bureaucracy to generate rents that could be harvested by 'insider' firms, while also encouraging it to extort money from 'outsider' firms and individuals. This necessitated incentives that would ensure strong loyalty and minimize internal opposition. Government entities were provided with insufficient budget funding to cover their costs, and their officials were expected to generate cash from illegal activities, making public sector employees financially dependent on corruption. Any employee who opposed this system could expect to be restricted to earning no more than the pitifully low formal salary entitlement. The system therefore became strongly self-reinforcing.
\end{abstract}

Keywords: corruption; public choice; bureaucratic reform; political monopoly; Indonesia

Some 10 years after former President Soeharto resigned from office, Indonesia has made impressive progress in relation to reform of its political system, but very little in relation to bureaucratic reform. The latter was perhaps the key promise of Susilo Bambang Yudhoyono (SBY) during his successful campaign for the presidency in 2004. Failure to deliver on this promise has been a major source of disappointment on the part of the general public, ${ }^{1}$ who had eagerly embraced the opportunity to elect their president directly for the first time (by virtue of a 2001 constitutional amendment). ${ }^{2}$ This is not to suggest that SBY has made no effort to improve the functioning of the bureaucracy. Rather,

1 According to a survey undertaken in May 2008, 59\% of respondents were either dissatisfied or very dissatisfied with the progress of reform during the post-Soeharto era, as against $31 \%$ who were sufficiently or very satisfied (Lingkaran Survei Indonesia, 2008).

2 Previously, presidents had been elected by the People's Consultative Assembly.

South East Asia Research, 16, 2, pp. 231-000 
the problem is that efforts to date have been misdirected. The focus has been almost exclusively on fighting corruption, but although there have been numerous prosecutions of quite high-level officials, plus some disruption of previous patterns of corrupt behaviour, there is little to suggest any significant reduction in its overall level. Indeed, the devolution of many of the powers of government to local level - itself a component of the post-Soeharto reforms - appears to have resulted in a proliferation of corruption, making life even more uncertain for the business community, on which Indonesia's economic progress heavily depends.

I shall argue here that corruption is only a symptom of a fundamental problem of inappropriate personnel management practices in the bureaucracy, and that these are a part of the Soeharto legacy, having been designed for a bureaucracy that was intended to be corrupt. The system of incentives facing civil servants was not designed to achieve effectiveness in terms of pursuing the interests of the general public, but to encourage loyalty to the regime; the consequence of this is that postSoeharto presidents have been hobbled by a bureaucracy that performs well below the level of competence that would be possible with a better designed system. Low bureaucratic effectiveness has significant implications for economic growth, since the private sector depends on the bureaucracy to provide complementary inputs such as physical and legal infrastructure.

\section{The Soeharto franchise}

To gain a clear understanding of how the Soeharto regime functioned, it is essential first to set aside the idealized notion of government in the public interest. Thus I argue here that Indonesia's former president moulded the five major components of the public sector into a 'franchise' system (Figure 1), the fundamental purpose of which was to use the coercive power of government privately to tax the general public and redistribute the tax revenue to a small elite. Government was not 'of the people, by the people and for the people', but rather 'of the people, by and for the controlling elite'.

The first branch of the franchise encompassed the legislature and the political parties. There were only three parties, one of which was Soeharto's election vehicle, Golkar. The other two were tame parties that had been formed by forced amalgamations of a greater number of parties that had existed in years gone by. The second branch of the 


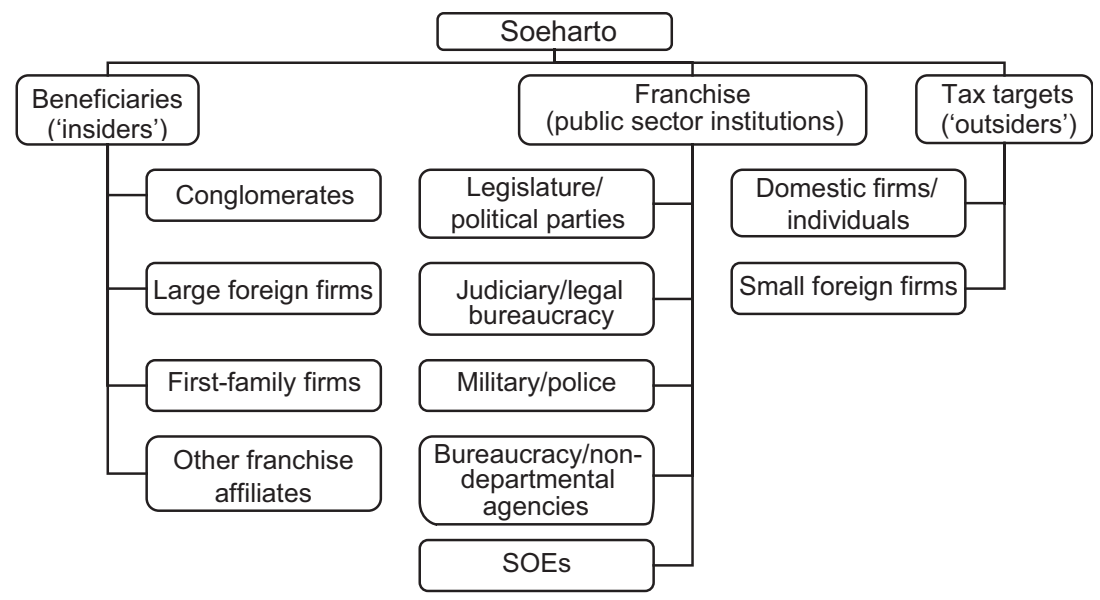

Figure 1. Soeharto's franchise system.

franchise comprised the bureaucracy - that is, all of the government departments, plus a number of non-department agencies (such as the logistics agency, Bulog, and the central bank, Bank Indonesia). The third element - technically part of the bureaucracy, but worth considering as a distinct component in its own right - was the judiciary and the associated legal bureaucracy, such as the Attorney General's office and the Department of Justice. Fourth was the military, which, under Soeharto, also included the police. ${ }^{3}$ Finally, we come to the numerous state-owned enterprises (SOEs), many of which were previously owned by the Dutch, but were nationalized in the 1950s; these were spread over a wide range of sectors of the economy, such as banking and finance, natural resources, transportation, retailing, plantation agriculture and so on.

The core activity of this giant franchise was located in the bureaucracy and, to a lesser extent, the state enterprises. One of the two key functions of the bureaucracy was to implement policies that would generate rents on behalf of the beneficiaries of the franchise system. These 'insider' beneficiary firms included the so-called 'conglomerates' (that is, large, diversified business groups owned by cronies of the president, most of which were owned by ethnic Chinese); a number of large foreign firms permitted to operate in Indonesia, almost always in partnership with some local entity favoured by the regime; companies owned

3 In recent years, the police force has been separated from the armed forces. 
by the first family (that is, relatives of the president himself) $;^{4}$ and companies owned by franchisees (numerous officials at various levels within the public sector institutions) and their families. Rents could be generated in countless ways by the bureaucracy for each of these beneficiary groups. A simple example from the early days of the regime was the granting of exclusive rights to import cloves - the all-important special ingredient in Indonesia's famous clove cigarettes, or kretek - to just two firms, one owned by the president's half-brother, Probosutedjo, the other by one of his closest cronies, Liem Sioe Liong. Another type of monopoly was that enjoyed by individuals - often serving or retired military officials - designated as concessionaires with the sole right to undertake logging in large parts of Indonesia's vast rainforests. ${ }^{5}$

Monopolies and concessions of one kind or another were just two of the means by which the beneficiaries of the franchise could be virtually guaranteed to earn very high profits, which were then to be shared with Soeharto and his family members, and with highly placed members of the franchise. ${ }^{6}$ The state-owned enterprises were also used as a means of enriching the beneficiaries of the franchise system, most obviously the conglomerates and first-family companies. Firms in these groups engaged in business transactions with SOEs at artificially determined prices favourable to themselves. Loans from state banks carried below-market interest rates, and quite often had the enormous added benefit of not having to be repaid. Fuel could be purchased at below-market prices from the giant state oil company, Pertamina. Airport space and facilities could be rented from state-owned airport operators at below-market rates, again with the added bonus of perhaps indefinitely delayed payment.

The same kind of symbiotic relationship as that which existed between the president and big business was replicated on a smaller scale at ministerial level and below, as well as in regional governments throughout

4 This group became increasingly important and significant in the economy as Soeharto's children grew to become adults and began to establish businesses of their own, rather than in partnership with their father's cronies.

5 These were monopolists in the sense that they were simply awarded concessions by government fiat, rather than needing to bid in competition with other firms for the right to $\log$ the concession areas.

6 Two important techniques for rent sharing were donations by the insider firms to a number of non-transparent and non-taxable foundations controlled by the regime, and the issue of shares in these firms, free of charge, to family members of the franchisor and franchisees. 
the country. Provincial governors, mayors and heads of districts, subdistricts and even villages, along with their bureaucrats and administrators, were encouraged - indeed, expected - to act in similar manner. When opportunities existed for government officials at any level to use their authority in ways that generated excess profits for favoured businesses, this was precisely what occurred. Obvious examples include awarding overpriced contracts for the construction of public works, government buildings and so on, or for the supply of equipment and materials to government offices, schools and healthcare facilities, and even for catering for official gatherings of one kind or another. Enterprises and banks owned by lower-level governments were also used to generate excess profits for favoured private sector businesses.

While insider firms harvested the rents generated for them by the bureaucracy, other 'outsider' private sector firms and individuals served instead as targets for predation. Franchisees within the bureaucracy and the military/police were expected by Soeharto to generate additional income via extortion from these firms and individuals, including smaller foreign firms, and to share the proceeds with him. Bureaucratic extortion usually took the form of requiring bribes as a condition for the issue of licences, the delivery of normal public services, and so on, while extortion of a more overtly criminal nature, involving the use or threat of violence, was undertaken by the military, ${ }^{7}$ often working through private sector subcontractors - thugs and criminal gangs known as preman. The military also generated large amounts of income through involvement in victimless crime - gambling, prostitution and drug trafficking - and through illegal exploitation of the nation's natural resources, such as forests, minerals and fisheries (Rieffel and Pramodharwardani, 2007).

The relationship between the public sector and outsiders was parasitic, while that between the public sector and insiders was symbiotic. But in both cases it was the general public that ended up paying the tax. The prices of products it purchased from the insider firms were artificially high. The prices of goods and services purchased on its behalf by the government were artificially high; and the prices of goods and services sold to insider firms by state enterprises were artificially low. The payments made by individuals in response to bureaucratic

Soeharto himself had previously been involved in such activity, and 'was dismissed from his position as commander of the Diponegoro Division in Central Java in October 1959 for demanding money from local businesses' (Rieffel and Pramodharwardani, 2007, p 31). 
and military/police extortion differed only in that they were quite transparent to the 'taxpayer'.

The analogy with franchises in the world of commerce is useful for understanding the way in which the Soeharto regime operated. It is worth thinking carefully about such matters, because Soeharto delivered highly effective government - achieving rapid growth sustained over some three decades - notwithstanding the corrupt and anti-democratic character of his regime. It is important to understand aspects of the franchise that explain its success, and also to understand aspects of the Soeharto legacy that now stand in the way of Indonesia's economic progress.

The basic characteristics of franchises in the business world include: a contractual relationship between a franchisor and multiple franchisees; payment of an entry fee by those wishing to join the franchise, together with further regular payments to the franchisor in order to maintain their membership; and delegation of management of local aspects of the individual franchise operating unit to the franchisees. The key to success is the franchisor, who has the right and responsibility to design the products sold, and to determine the overall operating parameters for the way they are delivered to customers. Thus, for example, every Starbucks outlet looks much the same and sells much the same range of products, wherever in the world it is located; likewise for Kentucky Fried Chicken, Pizza Hut, and so on.

In this case, the 'product' was the right to make use of the coercive power of government to impose 'private taxation' on the general public, whether by means of bureaucratic or conventional extortion, or by artificially boosting the profitability of insider firms at the expense of the general public (and then sharing the excess profit harvest with the beneficiary companies). The revenues collected were for the private benefit of individual members of the franchise and of the 'owner' of the franchise, Soeharto. In order to join the franchise or to move to a higher level within it - for example, by being appointed as a provincial governor or district head, or to a position of authority in one of the ministries, or to a court in one of the main commercial centres, or to a management position in one of the state enterprises - the individual was required to make a payment in some form, directly or indirectly (through higher-level franchisees) to the franchisor. This can best be considered as the upfront payment of a share of revenues expected to be received in the future by virtue of the exercise of the power to extort from individuals and firms, or to generate and share in rents harvested by insider firms. 
The franchise concept elaborated here should be distinguished from treatments of government in the public choice literature, a key advance in which was to drop the implicit assumption that government bureaucrats strove selflessly to promote the public good -assuming instead that they, like everyone else, were motivated by self-interest (see, for example, Buchanan and Tullock, 1962; Krueger, 1974; Posner, 1974). But this literature, very largely built up within the context of democracy as practised in the USA, took for granted a free and fair electoral system in which the government of the day was obliged by the threat of being voted out of office to constrain the pursuit of bureaucratic selfinterest. The present paper replaces the implicit assumption of free and fair elections with an assumption that the government itself - or, more precisely, its leader - deliberately and successfully sets about acquiring (and maintaining) a political monopoly. Whereas a large part of this earlier literature focuses on 'rent-seeking', the emphasis here is on 'rent generation and harvesting'.

By any measure, the Soeharto franchise was spectacularly successful in its objective of generating wealth for its members and cronies. Pre-crisis estimates of the net worth of the Soeharto family run to many billions of dollars, while cronies such as Liem Sioe Liong became among the richest individuals in Asia. Countless high-level bureaucrats, military officials, state enterprise managers and judges became fabulously wealthy relative to their miserably small official salaries. One of the keys to success was the fact that the regime was able to maintain a very high average annual rate of economic growth (well over $7 \%$ in real terms) over some three decades; very few countries in the world are able to boast a similar achievement. Of course, the regime collapsed in fairly spectacular fashion in 1998, and the economy headed into a very deep recession. But although economic output fell by $13 \%$ in that year, conditions were able to be stabilized quite quickly after the regime change, and by 2000 the economy had returned to growth at annual rates of around $5 \%$.

Even taking into account the major setback at the end of the 1990s, Soeharto left Indonesia's economy, and most of its people, considerably better off than they had been when he first came to power, notwithstanding the large-scale redistribution of income from the general public to the elite. For example, anthropologists Irwan Abdullah and Ben White describe the changes they observed between the early 1970s and the late 1990s in a village close to the provincial capital of Yogyakarta, as follows (Abdullah and White, 2006, p 60): 
'... many signs of material improvement were obvious. Improved roads and a new bridge had cut the travel time to the city of Yogyakarta by about $40 \%$... The quality of housing was much improved; nearly all houses have had access to electricity since the mid-1980s and more than half of all households now have TV sets at home (there was no TV or electricity in the village in 1972-1973). ... rice yields [were] about twice their former levels ...'

Elsewhere, I have argued that the important distinction between Soeharto and most other developing country dictators or regimes is that he had an implicit understanding of the logic behind the so-called 'Laffer curve': that maximizing tax revenue (whether public or private tax) involves keeping the rate of taxation modest, since high tax rates have the effect of encouraging tax avoidance and evasion, or even driving the taxed activity out of existence (McLeod, 2000, pp 105-106). The Soeharto franchise owed its success to its ability to impose private taxation at a relatively low rate but on a very wide tax base - effectively involving the entire economy and its supporting natural resources. The contrast with highly destructive dictatorial regimes such as those in developing countries like Nigeria and Zimbabwe, where private taxation was levied at high rates that took no account of their longer-term implications, could not be more stark.

Since the effectiveness of any organization depends on the behaviour of the individuals that comprise it, Soeharto's principal concern as 'owner' of the franchise was to create a set of incentives for individuals within it that would guarantee its success. An important concern of this paper is to elaborate the nature of these incentives.

As is the case with commercial franchises in the world of business, the basic incentive to high performance of franchisees is the monetary return this brings. Individuals are willing to buy into the franchise if they expect monetary rewards that would reflect a reasonable return on this investment. As we have just noted, countless individuals were able to achieve huge increases in their net worth during their working careers by virtue of their success as franchisees. There have always been numerous applicants for positions in the civil service and the military relative to the number of such positions available at any time, and individuals have always been willing to make under-the-counter payments to the relevant 'gatekeepers' to secure such positions, or to secure promotions and transfers to more lucrative postings once inside the system. Observations such as these are clearly indicative of the strong financial incentives facing New Order franchisees. 
Another similarity with ordinary business franchises was the existence of a process of 'natural selection' that contributed to overall success. Individuals who buy into commercial franchises but find that they make an inadequate return on their investment typically sell out to others who think they can do better. Those who meet with greater success tend to move to higher levels in the organization or to increase the number of franchise outlets under their control. In the Soeharto franchise, individual performance relative to the objectives of the franchise was constantly monitored, and franchisees were continuously assigned and reassigned to positions that reflected their performance. In other words, the less successful franchisees found themselves shifted sideways as they were replaced by others willing to bid more for their positions, or who had persuaded officials at higher levels that they were capable of superior performance - and therefore of making greater financial and other contributions to the franchise - than those of the incumbents.

On the other hand, Soeharto could not rely solely on positive monetary incentives for the effectiveness of the franchise arrangements. He also had to concern himself with the fact that by no means all individuals employed in the public sector would willingly or enthusiastically abuse their positions for private gain at the expense of the general public. The reality was that a significant proportion of individuals who joined the public sector hoped for nothing more than to be able to earn a reasonable day's pay from an honest day's work. Not only would such people be averse to the idea of privately taxing the general public for their own benefit, but many of them could be expected to oppose the system and to expose others who actively supported its operations. Clearly, the franchise idea could not be successful if individuals of high integrity were able to block, or seriously disrupt, the processes that generated income redistribution in favour of the elite. For this reason it was necessary to create a set of negative incentives as well.

\section{The judiciary as an example}

A useful case study of this aspect of the Soeharto strategy can be found in the history of the judiciary under the New Order, which has been discussed in extraordinary and colourful detail by Sebastiaan Pompe (2005). The following discussion relies heavily on this work. It is particularly apt to focus here on the judiciary, since independent courts 
would have represented an obvious conduit for challenges to the regime based on the illegality of key aspects of its functioning.

The role of the judiciary during the Soeharto era was relatively minor. Indeed, the regime had virtually no real commitment to the rule of law (notwithstanding abundant rhetoric to the contrary), and it is probably not too much of an exaggeration to suggest that, as with the trappings of democracy, it maintained a judiciary primarily for cosmetic purposes. Indonesian citizens and much of the world at large all took it as read that every nation state should have a freely elected legislature and a system of courts to ensure proper enforcement of the laws enacted by that legislature. The constitution therefore required there to be a parliament and a judiciary, and so the regime had to take the existence of these as a given, but its prime concern was to ensure that it controlled membership of the parliament and that the courts would pose no threat to itself or to its supporters. Thus, despite it being clearly stipulated in law that the judiciary should not be subject to interference from any outside party, ${ }^{8}$ in practice, Soeharto was able to make sure that it was in fact thoroughly subservient to his regime.

First, he made sure that the supreme court did not have the right to review the conformity of government legislation with the constitution, thus ruling out any challenge from the judiciary itself regarding the legal underpinnings of the regime's policies. Second, he made sure that personnel administration relating to the judiciary - that is, matters relating to appointments, transfers and promotions of judges - was under the control of the bureaucracy. ${ }^{9}$ Third, judges' salaries were tied to those in the civil service, which meant that they were kept to very low levels relative to those for individuals with similar legal skills and experience in the private sector.

The net effect of these second and third aspects was totally to destroy the independence of the judiciary - to ensure that it could be relied upon to protect and further the interests of the franchise. Judges could not earn an income commensurate with their professional status if they relied entirely on the base salary plus formal allowances. To achieve this, it became necessary for them to supplement their income in some manner, and the only realistic option was to accept direct or indirect 'gifts' from parties appearing in their courts. The best opportunities for generating a steady and substantial flow of such gifts were

Article 4 of Law 14/1970 on the Basic Principles of the Judiciary.

Article 31 of Law 14/1970 stipulated that judges were to be appointed and removed from office by the President. 
to be found in the major commercial centres, especially Jakarta; by contrast, any judge transferred to some small city in an outlying area would have very little scope for supplementing his or her income. But administrative authority over promotions and transfers was in the hands of the executive, and implemented through the Department of Justice. The implication was clear: judges either did what was expected of them by the regime - including making the 'right' decisions in cases in which the government had an interest, and making adequate financial contributions to the franchise in return for appointment to lucrative positions - or they would find themselves posted to a legal backwater where their careers would shrivel away, forcing them to live in virtual poverty relative to their professional status.

For a few years at the beginning of the New Order; there was a struggle between the government and the judiciary in relation to all of these matters, but the battle was eventually won decisively by the former with the passage of Law 14/1970 on Basic Principles of the Judiciary. As a result, the government was able thereafter to ensure a compliant judiciary, to such an extent that for the next quarter of a century it never lost a case in court. ${ }^{10}$

Given the fact of its existence by virtue of constitutional requirement, if nothing else, the role of the judiciary and the associated legal bureaucracy was, to a considerable extent, simply to protect the franchise against various kinds of challenge. Vocal critics of the regime could be silenced by putting them in jail, for example. Well known examples include labour activist Mochtar Pakpahan (sentenced to four years' imprisonment for engineering a strike in Medan in 1994), political maverick Sri Bintang Pamungkas (sentenced to nearly three years' imprisonment in 1996 for insulting the head of state, and sued in 1997 for subversion for setting up a new political party and calling for Soeharto's resignation), and student leader Budiman Sudjatmiko (sentenced to 13 years in prison for publishing a political tract criticizing the government in 1997) (Pompe, 2005, pp 164-171). Likewise, the courts could be used to help suppress, rather than protect, the freedom of expression supposedly guaranteed by the Press Law. The most notorious example is that of the highly respected weekly, Tempo, which had its publication permit withdrawn in 1994. Although it won its challenge to this action in the district court, before long the government successfully appealed this decision in the supreme court (Steele, 2005).

10 More precisely: it did lose a few cases in the district courts and even occasionally in the supreme court, but was always able to have these decisions overturned on appeal. 
Broadly speaking, the state could more or less do what it wanted with its citizens without having to fear that the judiciary would find against it in any case brought to the courts. The extent to which judges, the courts and the police did provide basic law enforcement services for the benefit of the general public was minimal. Just as petty bureaucrats needed some form of inducement to certify compliance with a regulation, so bribes were usually needed to get the police even to attend the scene of a crime, or to obtain a favourable judgment in court. Indonesia's citizens never really thought of themselves or their property as being well protected by any part of the law enforcement apparatus under the New Order. But both the judiciary and the military could certainly be relied on to protect the integrity of the franchise itself, the former using the mechanisms of the court, and the latter relying simply on violence or the threat of violence.

It is all too easy to condemn individual judges for allowing themselves to become involved in corrupt activity and to be used as an instrument of oppression by the regime, as they had been placed in an almost impossible position. The older generation, at least, had invested several years in studying the law and preparing themselves for a lifetime career in the judiciary, but when the time came, they found that it was practically impossible to apply the law with integrity: the franchise system simply did not allow them to do so.

Of course, any judge could have made a protest against the regime by finding for the plaintiff in some case in which the government or one of its supporters was on the opposing side. But any such decision would inevitably be overturned on appeal to a higher court, and the judge in question would find his or her career in ruins. That said, the argument that it was impossible to fight against the system provided a convenient justification for those judges who eagerly embraced the opportunity to enrich themselves corruptly - especially younger ones who had taken on this career when the nature of the system had already become obvious. In any case, the point of this essay is not to pass judgment on judges, but simply to illustrate the nature of the system in operation - and, by implication, to point out the kinds of changes to managing the judicial system that are necessary if corruption is to be minimized and the quality of judicial decisions significantly improved.

The history of the judiciary under the New Order clearly illustrates the key features of the Soeharto strategy for ensuring that most members of the franchise institutions would support the franchise, and that few would oppose it. Setting judicial salaries at or near comparable 
market rates would have been counterproductive. First, it would have increased the amount of legitimate taxation revenue required, thus reducing the scope of the franchise for generating private tax revenue. More importantly, it would have put judges in a position where they could act against the regime in court cases brought against the government, without having to forego a standard of living appropriate for individuals of their professional status. Conversely, the imposition of very low salaries relative to comparable private sector levels ensured that judges would be forced to play by the rules of the franchise, or else to leave the judiciary, if they were to enjoy such a standard of living. The consequences for members of the judiciary varied widely. Those who were unwilling to do the bidding of the regime found themselves languishing indefinitely in far distant outposts, with few fringe benefits, little work to occupy their time or hone their skills, and no hope for a 'successful' career in any sense of the term. At the other end of the spectrum, those who, like the president, enthusiastically embraced the notion of taking advantage of their positions to achieve personal enrichment, were only too willing to do what was asked of them by the regime. Among the latter, those who were most effective were appointed to highly lucrative positions in the most active big city district courts, and some were promoted to the high courts or the supreme court.

\section{Public sector civilian employees as threats to the regime}

With this brief case study of the judiciary - technically part of the bureaucracy during the New Order - as background, we turn now to discuss in some detail the application of broadly the same kind of strategy to the bureaucracy as a whole. It would be unrealistic to suggest that the bulk of individuals employed in the bureaucracy when Soeharto came to office and who joined it subsequently intended to sacrifice their own interests in the service of their fellow citizens. No doubt many of them entered the bureaucracy (and other parts of the public sector) for the same reason that others took up private sector employment: simply to earn a living. It can safely be assumed, however, that many of these individuals and other potential entrants would have been appalled by the notion of government as an instrument for redistributing income to the elite. One of the key problems Soeharto faced, therefore, as argued above, was to ensure that civil service bureaucrats would at least acquiesce in the face of common knowledge as to what the franchise was about, and certainly not actively oppose it. 
An important characteristic of New Order strategy was that public sector institutions typically were not provided with sufficient funding from the budget to enable them to do much more than pay the salaries to which their employees were formally entitled. In turn, formal salary entitlements, especially for higher-level personnel, were set well below comparable levels in the private sector. The practical implication was that managers of these institutions had to find additional, off-budget sources of funds if they were to get things done and to provide additional allowances for their employees in order to secure their loyalty. Inevitably, this would involve engagement in various forms of activity that were either clearly corrupt, or at least were located within the fuzzy boundary that delimits corrupt and non-corrupt activity. Soeharto was very familiar with such circumstances from his days as an army commander, and could see the obvious advantages of continuing these kinds of arrangements. Thus, for example, despite the importance of the military's contribution to maintaining Soeharto's political monopoly, on which the success of the franchise depended,

'the military won little in the way of budget resources during the Soeharto era. ... By withholding budget funds, [Soeharto] gave military commanders a strong incentive to engage in income-generating activities. At the same time, his ability to grant or deny access to these activities fostered a high degree of loyalty and dependence among these commanders.' (Rieffel and Pramodhawardani, 2007, p 32)

In other words, Soeharto secured the loyalty of the military not so much by allocating government revenue to it, but by appointing its commanders as franchisees - by granting them the right to collect private tax revenues and to allocate them as they saw fit, including to their own pockets. The similarity with the case of the judiciary discussed above is obvious.

Within the bureaucracy, management would ordinarily devote part of the so-called 'development' budget, largely deriving from bilateral and multilateral aid agencies, to the payment of various allowances for example, to people who served on project committees (and, through them, to both their superiors and subordinates in the same area). This might seem like a clear case of misuse of government funds, since it amounted to people being paid extra simply for doing their jobs, but it must be remembered that the formal salaries of those same individuals were set well below comparable private sector salaries. In other words, to some extent this common practice simply brought overall remuneration up to fair (market) levels. Thus, the familiar argument that civil 
servants were and are 'forced' to engage in corrupt activity has some truth in it, but should not be taken too far. It is one thing to accept routine cash supplements that merely bring total remuneration up to market levels without asking too much about their provenance. It is another thing altogether to set about abusing one's position in order to become fabulously wealthy, out of all proportion to any reasonable return on one's skills and experience.

More obviously corrupt was the practice of awarding government contracts at inflated prices to firms that agreed to kick back a suitably large portion of the excess over reasonable market value to the officials or committees that awarded the contracts. These illicit payments were typically also used as slush funds for topping up the incomes of other employees of the government entity in question, although presumably the officials directly involved in negotiations would have taken a disproportionately large share. As mentioned earlier, this kind of activity amounted to reproduction on a small scale of the arrangements by which the franchise generated rents for conglomerates associated with the leadership of the regime and shared in those rents. The key point to note, however, is that the rents were shared widely within the relevant part of the bureaucracy. In this manner, large numbers of officials, especially those at the higher levels where formal salaries were very low relative to market levels and compensating allowances were correspondingly high, became dependent on the continued operation of the system. It was highly unlikely that any individual would blow the whistle on such practices, because to do so would be to put at risk not only a significant part of one's own overall income, but also that of one's peers. As with the judiciary, lack of transparency within the system for transfers and promotions meant that such individuals could be severely punished by denying them promotion and access to informal allowances in cash and in kind to which there was no formal entitlement, or moving them to bureaucratic backwaters.

A key part of the solution to the problem of ensuring loyalty to the franchise can be seen in the public sector approach to determining the structure of employee remuneration (including basic salaries plus a wide range of formal allowances). ${ }^{11}$ If these had been set at levels comparable with those in the private sector, the public sector could have been staffed perfectly adequately for the purpose of undertaking what are

11 For earlier discussions of the nature, structure and consequences of public sector employee remuneration, see, for example, Smith (1975); Gray (1979); and Clark and Oey-Gardiner (1991). 
commonly regarded as the legitimate responsibilities of government. However, this would surely have resulted in the recruitment of large numbers of individuals who would have baulked at the abuse of the powers of government that characterized the Soeharto regime. The franchise could hardly have been successful under such conditions. Instead, the approach was to impose a salary structure that provided marketcomparable salaries at the lower levels of the civil service (where opportunities for supplementing one's income were very limited), but which kept salaries increasingly far below those for similarly qualified and experienced individuals in the private sector at the higher levels (where such opportunities were widespread). Thus the formal salary structure was greatly compressed: ratios of high-level to low-level salaries were much smaller than in large private sector organizations.

At first glance, this would appear to have made a career in the civil service thoroughly unattractive, except perhaps for those who did not aspire to promotions significantly beyond the lower ranks; and yet it was always the case that there were far more applicants for public sector positions than there were jobs available. ${ }^{12}$ To some extent, this could be explained by applicants having unrealistic perceptions as to the possibility of being recruited despite their limited educational achievements. The prospect of lifetime employment, a government pension beyond that, plus various other benefits such as subsidized family access to health services, free transport to the place of work and so on, was also important. More important, however, was the widespread and well founded perception that the income-earning potential of positions in the public sector was far greater than the formal salary structure suggested. In other words, it was well known that one could expect to receive a wide range of additional allowances of one kind or another, and that if one were so inclined there would be ample opportunity to be involved in lucrative corrupt activity.

In short, the kind of salary structure chosen for public sector institutions was such as to discourage the entry of highly principled individuals (which is not to deny that many such were recruited, nevertheless), and correspondingly to encourage that of people who at least would not

12 In her study of central Sumba, for example, Vel (2008) argues that 'the state is associated in a rather vague way with general opportunities for upward mobility, and more concretely imagined as a vast complex of secure employment and additional material benefits. The state is imagined as a rewarding patron, the gatekeeper to a more prosperous life and a secure employer. ... Sumbanese want to become part of this complex.' 
concern themselves too greatly about the sources of their special allowances or, better still, of those predisposed to engage actively in the work of the franchise. This is the only plausible explanation for the fact that individuals were willing to pay for the privilege of embarking on, and persevering with, a career characterized by increasingly large shortfalls below market salary levels the higher one rose in the hierarchy.

Decisions had to be made not only about the public sector salary structure, but also about the number of employees. Indonesia's civil service under Soeharto was never particularly large,,$^{13}$ and yet, in relation to the fairly narrow objectives of the franchise, the number of public sector employees seems at first glance to have been unnecessarily great. This impression is no doubt heavily influenced by the obvious degree of underemployment within the bureaucracy, which was quickly apparent to visitors to virtually any government office building.

Early in the New Order, Soeharto decided to adopt personnel management practices within the bureaucracy that mirrored those he had been used to in the army. One aspect of this was a rigid pyramidal hierarchy, in which the commanding officer would have a fixed number of subordinates reporting to him, each of whom would have a fixed number reporting to him, and so on down to the level of private. Thus all battalions, all regiments and so on would have the same number of individuals at each level in the hierarchy. Whatever its merits in the military context, such an approach made little sense within the bureaucracy, because different agencies were involved in widely varying activities, and their staffing needs differed correspondingly (Synnerstrom, 2007, pp 164-165). There was no reason why we would expect the staffing needs of, say, the Department of Public Works to match those of the Department of Education. Nevertheless, the benefit to the franchise was that this approach typically resulted in excessive numbers of bureaucrats at low levels and insufficient numbers of them at high levels. The rampant underemployment of staff just mentioned was in fact a characteristic only of low-level employees; by contrast, those at high levels were quite often heavily overworked. The implication was that relatively few at the low levels could expect rapid promotion, and yet promotion was the only way to gain access to the more lucrative opportunities for supplementing one's income with special allowances paid from the slush funds or through participation in corrupt

13 In 1997 (Soeharto's last year in office), Indonesia had 4.1 million civil servants, equivalent to just $2 \%$ of the population. 
activity. In these circumstances, individuals desirous of promotion had strong incentives to compete with their peers - especially for promotion into positions in the 'wet' areas, where the availability of off-budget funds was greatest.

Such competition took a variety of forms, and working hard was by no means the only one. The process for determining promotions and transfers within the bureaucracy lacked transparency and objectivity, and relations with one's own superior were, in practice, the crucially important deciding factor - hence the prevalent culture of asal bapak senang - 'as long as the boss is happy' - within the Indonesian bureaucracy. Recall that management of franchises at the local level is typically delegated to the franchisee, who is then more or less free to choose which of his subordinates to promote or transfer to positions of greater authority and which to leave where they are or to shift to positions of little influence. In the context of the franchise, in which the primary objective was regressive redistribution of the national income rather than the delivery of services to the public, it is hardly surprising that competition also often took the form of bidding for desirable positions.

'In Indonesia, most civil service positions are for sale, rather than being acquired in open competition based on merit. The practice of selling civil service jobs goes hand in hand with corruption more generally - from one per-spective, the investment needed to obtain a $\bar{\equiv}$ position needs to be recov-ered; from another, the likelihood of access to lucrative opportunities for self-enrichment makes such an investment worthwhile.' (Synnerstrom, 2007, p 174)

The winners of the competition were those who bid the highest prices to those who determined who would be promoted or appointed to particular positions, and these were typically those who had the greatest confidence in their ability to abuse these prospective positions of authority to generate cash inflows. That is, just as the salary structure encouraged recruitment of the kinds of individuals who would serve the franchise well, so the hierarchical structure within the bureaucracy reinforced this tendency by encouraging the promotion of the same kinds of individuals after they had had a chance to demonstrate to their superiors and to themselves their capacity and willingness to contribute to the objectives of the franchise.

There was perhaps one additional reason for recruiting what may 
seem like excessive numbers of high school and university graduates to the public sector. ${ }^{14}$ The regime had decided to increase significantly the number of children and young people attending schools and universities, since this was clearly a way of generating support from the public and thus offsetting concerns that the government cared only about its big business friends. But students have always been quite a potent political force in Indonesia (Aspinall, 2005, chapter 5), so it made sense to hold out the enticing prospect of a well remunerated career in the civil service following graduation, because students - and their parents - would have been well aware that involvement in student activism directed against the regime would very likely ruin any chance of being recruited. The strategy of offering eventual access to lucrative positions in the franchise to those who demonstrated their willingness to accept it for what it was, thus extended even to potential public sector employees.

Allowing members of the public sector branches of the franchise to tap into foreign aid flows and to collude with private sector firms engaged in economic transactions with the public sector constituted useful and effective means of allowing public sector employees to top up their formal remuneration and thus to ensure their support for the broad objectives of the franchise. But there were, of course, additional means of doing this. Recall here the distinction introduced earlier between insiders and outsiders. The insiders were the privileged firms that cooperated with the franchise so as indirectly to tax those outside the elite in one way or another. The outsider firms and individuals, on the other hand, were the targets rather than the beneficiaries of such taxation, and they were taxed by way of bureaucratic extortion. Broadly speaking, the bureaucracy created a wide range of regulations with which firms needed to comply, and then found ways of forcing firms to pay bribes in order to obtain certification of such compliance. In addition, it accepted bribes from firms wishing to reduce, or avoid altogether, their payments of legitimate taxes, such as customs duties, value added tax and income tax. ${ }^{15}$

14 In $1997,83 \%$ of civil servants were graduates of senior high school or tertiary institutions.

15 Outsider firms and individuals were also subject to extortion by the military/police, involving the employment of violence or the threat of violence to persuade them to contribute to their own 'protection'. The small but relatively wealthy ethnic Chinese community was always particularly vulnerable, and some of its members found it prudent to try to keep local military officials favourably disposed to it (Susanto, 2006). But indigenous [pribumi] citizens were also targets. 
It is because of the heavy emphasis on public sector extortion from firms and individuals that Indonesia has such a poor image in relation to corruption and bureaucratic inefficiency (Kaufmann, Kraay and Mastruzzi, 2006; World Bank, 2006; see further discussion below). Indonesia's rapid economic progress under Soeharto is somewhat paradoxical when viewed against this background. The paradox is readily resolved, however, when we recall the existence of insider firms, which collectively accounted for a very large share of the modern sector of the economy, and which were not only broadly immune to such extortion but in fact benefited strongly from their privileged relationship with the bureaucracy, the state enterprises and the public sector in general.

\section{Post-Soeharto reform}

The Asian financial crisis that began in mid-1997 suddenly created turmoil in Indonesia, depriving the New Order regime of its legitimacy as a sound economic manager. In turn, this simultaneously emboldened opponents of the regime and dramatically weakened Soeharto's ability to maintain discipline within the franchise, such that its various branches and members no longer continued to act in a mutually supportive fashion. As a result, he was pushed out of office in May 1998, and reformers moved very quickly to overturn several key features of the regime he had built up over the previous three decades. Relatively little progress has been made in reforming the bureaucracy, however, which remains highly dysfunctional.

There can be no doubt that the bureaucracy inherited by President Susilo Bambang Yudhoyono (SBY) and the three previous post-Soeharto presidents is highly corrupt. Surveys such as those undertaken by Transparency International suggest that Indonesia is one of the most corrupt countries in the world (ranked at equal $130^{\text {th }}$ out of 163 countries in Transparency International's Corruption Perceptions Index for 2006). ${ }^{16}$ Other sources, such as the World Bank's Governance Matters and Doing Business reports (Kaufmann, Kraay and Mastruzzi, 2006; World Bank, 2006) show clearly that it is also very inefficient, and emphasize the deleterious impact of this inefficiency on the business and investment environment. For example, Indonesia was ranked only in the $37^{\text {th }}$ percentile in terms of 'government effectiveness' in the 2005 Governance

16 See Website: http://www.transparency.org. On this index, the closer the numerical ranking to 1 , the less severe the perceived problem of corruption. 
Table 1. Ease of doing business in Indonesia: selected sub-indices and components.

\begin{tabular}{lccc}
\hline Indicator & Measure & Rank (among 155 countries) \\
Overall ease of doing business & & & 115 \\
Starting a business & & 149 & 144 \\
$\quad$ Time & 151 days & 121 & \\
Cost (\% of income per capita) & $101.7 \%$ & 122 & 120 \\
Hiring and firing workers & & 63 & \\
Difficulty of Hiring Index (0-100) & 61 & 131 & \\
Rigidity of Hours Index (0-100) & 40 & 53 & 118 \\
Difficulty of Firing Index (0-100) & 70 & 150 & 107 \\
Hiring cost (\% of salary) & $10.2 \%$ & 119 & \\
Firing costs (weeks of wages) & 144.8 weeks & & \\
Paying taxes & 560 hours & 60 & \\
$\quad$ Time & & 126 & \\
Registering property & 42 days & 98 & \\
Time & $11.0 \%$ & 104 & \\
Cost (\% of property value) & 224 days & & \\
Dealing with licences & $364.9 \%$ & & \\
Time & & & \\
Cost (\% of income per capita) & & \\
\hline
\end{tabular}

Source: World Bank, 2006.

Note: The closer the numerical rank to 1 , the easier it is perceived to do business.

Matters report. ${ }^{17}$ At the same time, its world ranking on a number of important standardized indicators of the ease of doing business (as this relates to the influence of the bureaucracy) can also be seen to be very low (Table 1). Indeed, the government itself is well aware of the problem, and has been at pains to proclaim the seriousness with which it is trying to deal with it; yet it seems to have no clue as to why the bureaucracy is both corrupt and inefficient - implicitly putting the blame on human failings (which must largely be taken as a given) rather than the design of existing institutional arrangements.

The bureaucracy succeeded in generating consistently high economic growth during the New Order period because this was in the interests of the franchise, and because there were strong incentives for success within it. The franchise prospered by taxing virtually the entire economy, so the faster the economy grew, the greater the pay-off. But in the entirely different context of post-Soeharto democratic Indonesia, the bureaucracy as economic policy maker has been found wanting. The franchise no longer exists, since there is no longer a franchisor capable

17 On this index, the lower the percentile rank, the less effective government is perceived to be. 
of imposing discipline on all of its branches: this became an impossibility once Soeharto's monopoly on the presidency was removed. Its collapse following Soeharto's demise is very closely analogous to the breakdown of a cartel as a result of its individual members' failure to restrict their output to agreed quotas: cartels cannot survive in the absence of internal discipline. Individuals still have an incentive to abuse their authority to their own advantage, but they now do so in uncoordinated fashion, competing with each other rather than playing defined, mutually supportive roles within the giant organism that is the Indonesian public sector.

The previous strategy of promoting civil servants on the basis of their loyalty and usefulness to the franchise, rather than their ability to discern what constituted sound policy, has left the bureaucracy very short of the skills and competence needed in most if not all fields, including economics. There are large numbers of bureaucrats in the economic ministries and the central bank in a position to influence economic policy, the majority of whom appear to favour interventionist approaches rather than simply allowing market forces and private sector firms largely to determine the process of economic growth.

Two factors drive this interventionism. First, bureaucrats inherited by post-Soeharto governments are well aware from past experience how intervention in markets can be used to extort money from the private sector. Thus, for example, it came as no surprise when the new Investment Law (Law 25/2007) failed to recast the Investment Coordination Board (BKPM) as an investment promotion agency rather than an investment regulating agency as it always had been during the New Order (Manning and Roesad, 2006, p 158). In this and countless other areas, the desirable direction of reform involves rolling back government controls in order to deprive the bureaucracy of its power to extort from the private sector, but this, of course, runs directly counter to the personal interests of the officials who administer them.

The proclivity for interventionism is often driven by genuine conviction rather than being purely self-serving, however. The second major underlying factor is that many bureaucrats involved with economic policy making have inadequate - if any - professional economics training. ${ }^{18}$ Interest groups throughout the economy find useful allies among such policy makers, who lack the analytical skills to be able to distinguish

18 Many 'economist' bureaucrats actually specialized in the related areas of accountancy and business management, rather than economics itself, when undertaking their degrees. 
the interests of these groups from those of the general public. Indonesia is no different from other countries in this respect, of course.

The list of interventionist policies favoured by such policy makers is so long that it is not practical to mention them all here - much less analyse their distributional and efficiency consequences in detail - but it includes the following: special tax treatment to encourage particular kinds of manufacturing; price supports and subsidized inputs for farmers; protection of domestic firms from import competition (a policy that is now frequently found at the regional level as well as nationally); provision of subsidized loans for small businesses; regulation of workers' wages and other entitlements; opposition to the divestment of majority shares of state firms to private sector entities; and bureaucratic planning rather than reliance on markets to determine the directions of structural change in the economy and in particular sectors. In each case, it is not difficult to mount a strong argument that the gains to those who benefit from intervention are outweighed by aggregate losses to the general public, although this would take us well beyond the scope of this paper.

In short, the bureaucracy often lacks a clear idea of what constitutes sound economic policy; ${ }^{19}$ and even when the broad thrust of its policies is more firmly based, it often proves incapable of implementation. ${ }^{20}$ The Soeharto legacy in terms of the bureaucracy is therefore not simply an ingrained culture of corruption, but also a pervasive lack of the skills necessary to manage such a large and complex economy as Indonesia's.

\section{Conclusion}

In this paper, I have attempted to show how the Soeharto regime managed the economy and polity of Indonesia for the benefit of the dominant elite, rather than for Indonesian citizens in general. I have argued that his franchise was extraordinarily successful in terms of its own objectives, and that this reflected the strategies employed to provide appropriate incentives to individuals within the several public sector

19 For example, in McLeod (2005), I discuss the potentially disastrous implications of creation of the new Deposit Guarantee Institution, which seems to indicate that policy makers in the Ministry of Finance and the central bank have learned little from the meltdown of the banking system in 1998 .

20 The inability to formulate the kinds of policies needed if the government is to succeed in its aim of involving the private sector in the provision of infrastructure is an obvious case in point (McLeod, 2005, pp 144-146). 
branches of his franchise. Soeharto set the formal salaries of his franchisees low relative to market levels, and kept the operating budgets for most government entities small relative to their costs. At the same time, however, the franchisees were effectively granted the right to collect private taxation, backed by the full powers of the franchise. Positions as franchisees were thus eagerly sought after by those who had no qualms about using the coercive power of government for their personal benefit. Others who wanted nothing more than fair - that is, market-comparable - remuneration were obliged to suppress their moral concerns about the functioning of the franchise unless they were prepared to be left to languish in positions where they would have no real influence on the processes of government, and where their earnings would be far below a reasonable level for individuals of their professional status. The inadequacy of salaries and budgets forced franchisees to find ways to supplement the funds at their disposal, inevitably drawing them towards corrupt activity - thus making them dependent on, and unlikely to challenge, the status quo. Paradoxically, inadequate budgets and low salaries enabled Soeharto to buy support for the corrupt practices of his franchise.

\section{References}

Abdullah, I., and White, B. (2006), 'Harvesting and housebuilding: decline and persistence of reciprocal labour in a Javanese village, 1973-2000', in Koning, J., and Hüsken, F., eds, Rope Walking and Safety Nets: Local Ways of Managing Insecurities in Indonesia, Brill, Leiden and Boston, MA.

Aspinall, E. (2005), Opposing Soeharto: Compromise, Resistance, and Regime Change in Indonesia, Stanford University Press, Stanford, CA.

Buchanan, J. M., and Tullock, G. (1962), The Calculus of Consent, University of Michigan Press, Ann Arbor, MI.

Clark, D. H., and Oey-Gardiner, M. (1991), 'How Indonesian lecturers have adjusted to civil service compensation', Bulletin of Indonesian Economic Studies, Vol 27, No 3, pp 129-141.

Gray, C. (1979), 'Civil service compensation in Indonesia', Bulletin of Indonesian Economic Studies, Vol 15, No 1, pp 85-113.

Kaufmann, D., Kraay, A., and Mastruzzi, M. (2006), Governance Matters V: Aggregate and Individual Governance Indicators for 1996-2005, September, World Bank, Washington, DC, available from Website: www.worldbank.org/wbi/governance.

Krueger, A. (1974), 'The political economy of the rent-seeking society', American Economic Review, Vol 64, No 3, pp 291-303.

Lingkaran Survei Indonesia (2008), Survei Nasional, May, available from Website: http:/ /www.lsi.co.id/.

Manning, C., and Roesad, K. (2006), 'Survey of recent developments', Bulletin of Indonesian Economic Studies, Vol 42, No 2, pp 143-170.

McLeod, R. H. (2000), 'Soeharto's Indonesia: a better class of corruption', Agenda, Vol 7, No 2, pp 99-112. 
McLeod, R. H. (2005). 'Survey of recent developments', Bulletin of Indonesian Economic Studies, Vol 41, No 2, pp 133-157.

McLeod, R. H. (2006), 'Indonesia's new Deposit Guarantee Law', Bulletin of Indonesian Economic Studies, Vol 42, No 1, pp 59-78.

Pompe, S. (2005), The Indonesian Supreme Court: A Study of Institutional Collapse, Cornell South-East Asia Program Publications, Ithaca, New York.

Posner, R. A. (1974), 'Theories of economic regulation', Bell Journal of Economics, Vol 5, pp 335-358.

Rieffel, L., and Pramodhawardani, J. (2007), Out of Business and On Budget: The Challenge of Military Financing in Indonesia, Brookings Institution Press and the US-Indonesian Society, Washington, DC.

Smith, T. (1975), 'Stimulating performance in the Indonesian bureaucracy: gaps in the administrator's tool kit', Economic Development and Cultural Change, Vol XXIII, No 4, pp 719-738.

Steele, J. E. (2005), Wars Within: The Story of Tempo, an Independent Magazine in Soeharto's Indonesia, Equinox Publishing, Jakarta, and Institute of Southeast Asian Studies, Singapore.

Susanto, A. (2006), 'Safety first: strategies of managing insecurity among Chinese Indonesians in Yogyakarta', in Koning, J., and Hüsken, F., eds, Rope Walking and Safety Nets: Local Ways of Managing Insecurities in Indonesia, Brill, Leiden and Boston, MA.

Synnerstrom, S. (2007), 'The civil service: towards efficiency, effectiveness and honesty', in McLeod, R. H., and MacIntyre, A., eds, Indonesia: Democracy and the Promise of Good Governance, Institute of Southeast Asian Studies, Singapore, pp $159-177$.

Vel, J. (2008). 'Reading politics from the book of donations: the moral economy of corruption in Sumba', in van Klinken, G., and Barker, J., eds, State of Authority: State in Society in Indonesia (forthcoming).

World Bank (2006), Doing Business in 2006: Creating Jobs, World Bank and International Finance Corporation, Washington, DC, available from Website: http:// publications.worldbank.org/ecommerce/catalog/product?item_id=1385010. 